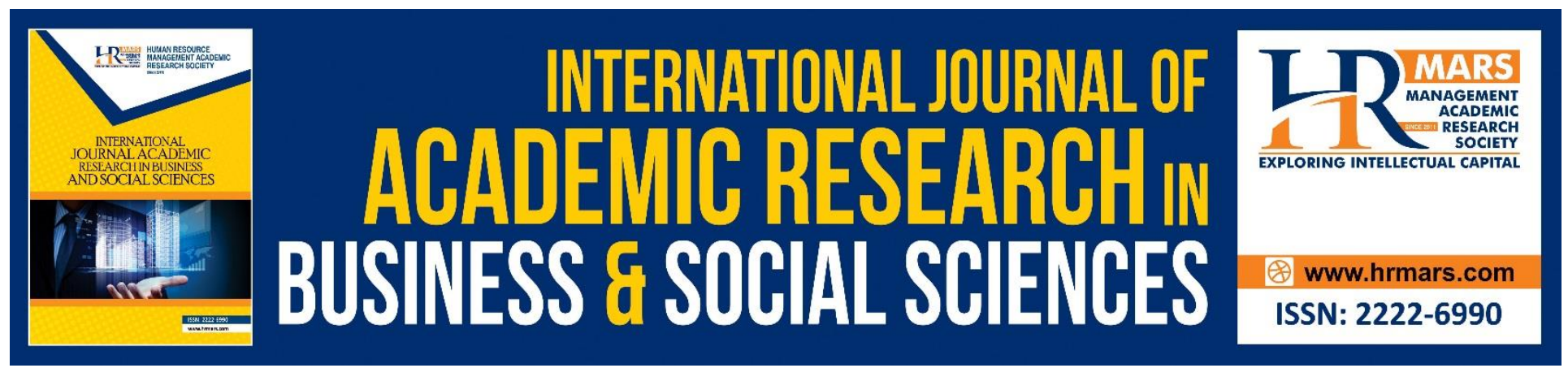

\title{
Development of School's Sports Safety Audit Tools (3sat)
}

Julismah Jani, Mai Shihah Abdullah, Mohd Izwan Shahril, Rozaireen Muszali, Mohd. Esa Baruji, \& Muhammad Amirul Adnan

To Link this Article: http://dx.doi.org/10.6007/IJARBSS/v10-i9/7679

DOI:10.6007/IJARBSS/v10-i9/7679

Received: 01 June 2020, Revised: 02 July 2020, Accepted: 16 August 2020

Published Online: 10 September 2020

In-Text Citation: (Jani, Abdullah, Shahril, Muszali, Baruji, \& Adnan, 2020)

To Cite this Article: Jani, J., Abdullah, M. S., Shahril, M. I., Muszali, R., Baruji, M. E., \& Adnan, M. A. (2020). Development of School's Sports Safety Audit Tools (3sat). International Journal of Academic Research in Business and Social Sciences 10(9), 1-15.

\section{Copyright: (C) 2020 The Author(s)}

Published by Human Resource Management Academic Research Society (www.hrmars.com)

This article is published under the Creative Commons Attribution (CC BY 4.0) license. Anyone may reproduce, distribute, translate and create derivative works of this article (for both commercial and non-commercial purposes), subject to full attribution to the original publication and authors. The full terms of this license may be seen

at: http://creativecommons.org/licences/by/4.0/legalcode

\section{Vol. 10, No. 9, 2020, Pg. 1 - 15}

Full Terms \& Conditions of access and use can be found at http://hrmars.com/index.php/pages/detail/publication-ethics 


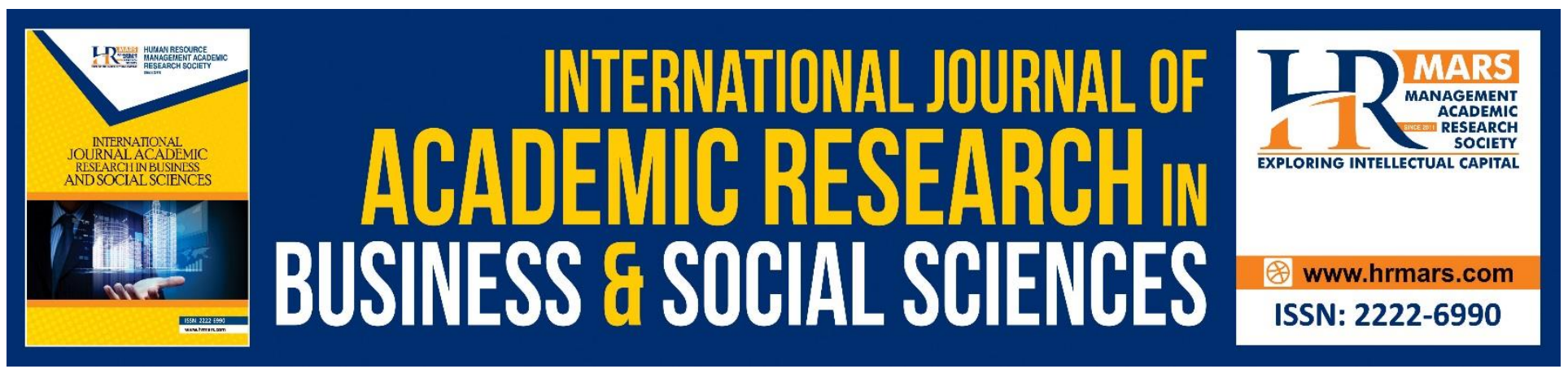

\title{
Development of School's Sports Safety Audit Tools (3sat)
}

\author{
${ }^{1}$ Julismah Jani, ${ }^{2}$ Mai Shihah Abdullah, ${ }^{3}$ Mohd Izwan Shahril, \\ ${ }^{4}$ Rozaireen Muszali, ${ }^{5}$ Mohd. Esa Baruji, \& ${ }^{6}$ Muhammad Amirul \\ Adnan \\ 1, 3, 4, ${ }^{6}$ Faculty of Sports Science and Coaching, Sultan Idris Education University, \\ Perak, Malaysia, ${ }^{2}{ }^{6}$ Faculty of Science and Mathematics, Sultan Idris Education University, Perak \\ Malaysia, ${ }^{5}$ National Institute of Occupational Safety and Health (NIOSH), Malaysia \\ Email: julismah@fsskj.upsi.edu.my
}

\section{Abstract}

The implementation of this study is to design, develop, test, and produce school's sports safety audit tool in order to assist schools to conduct safety audits on infrastructure, equipment and management of sports activities. The development of school's sports safety audit tool (3SAT) method is adapted from Stufflebeam's evaluation model (1983), which involves aspects of context, input, process, and product. In the aspect of context, the researchers conducted a retrospective conceptual analysis that identified factors of accidental incidents in sports that occurred in the school environment. Subsequently, the researchers obtained inputs to develop and design the contents of 3SAT based on documents such as Malaysia Ministry of Education Circular Letter on student safety in schools, School Occupational Safety and Health Program Handbook, Guidelines for Safety and Occupational Health Act 1994 (Act 514), Safe Schools Integrated Program Module, and Safe Schools Policies. For the evaluation process, the researchers obtained the validity of the content from 11 expert panels. A pilot study was conducted at selected schools to test and determine the reliability level of 3SAT. 3SAT consists of five types of audit on school infrastructure namely, Sports Store/Sports Management Room, Field, Open Court, Covered Open Hall, and Indoor Hall. The data obtained from the audit process were analyzed descriptively to identify the Sports Safety Index at the schools being studied. The expert panels agreed that the validity of 3SAT was excellent (91.70\%) and relevant to the content of the study. The reliability of 3SAT for Sports Store/Sports Management Room $(\alpha=.863)$, Field $(\alpha=$ $.842)$, and Open Court ( $\alpha=.816)$ were good and consistent. The reliability of 3SAT for Covered Open Hall $(\alpha=.738)$ and Indoor Hall $(\alpha=.647)$ were adequate, acceptable and consistent. In reference to the method of construction of 3SAT based on Stufflebeam's (1983) evaluation model, it was concluded that 3SAT has a very good validity and is relevant to the content of the study. The reliability level of 3SAT was also good, adequate, consistent and acceptable for this study. 3SAT is an audit report that provides inputs on indices and indicators to identify safety and risk factors for infrastructure facilities and sports activities management at schools. The audit report can be 
INTERNATIONAL JOURNAL OF ACADEMIC RESEARCH IN BUSINESS AND SOCIAL SCIENCES Vol. 10, No. 9, 2020, E-ISSN: 2222-6990 @ 2020 HRMARS

submitted periodically to Malaysia Ministry of Education. The report can be accessible to parents and public in order to assess their confidence in the safety of students at schools.

Keywords: Accident Incidents, Sports Safety, Audits on Safety, Audit Reports, Sports Safety Index.

\section{Introduction}

Malay proverb says "unexpected misfortune" and accidents can happen everywhere and at any time. News of accidents occurring in the school area is regularly reported in mass media every year. The most common accident incidents include being hit by goalposts in football play, health complications during sports activities, being hit by lightning at the school field while playing football and being attacked by snakes at school area. Table 1 is a chronology of students' death as a result of being hit by a goalpost while playing ball in school from the mass media source.

Table 1

Chronology of Student Death Accident Incidents due to Being Hit by Goalpost in Schools

\begin{tabular}{cccc}
\hline Year & Incident location & Level & Gender \\
\hline March 2000 & Kuantan district secondary school & Form Two & Male \\
January 2008 & Sungai Petani district primary school & Year Four & Male \\
November 2010 & Kepala Batas district primary school & Year Two & Male \\
September 2011 & Klang district primary school & Year Five & Male \\
July 2016 & Gua Musang district secondary school & Form Two & Male \\
\hline
\end{tabular}

The news of accident incidents related to health complications occurred in April, 2010 in which a remove class male student died of heart attack while attending his school's annual sports event in Bukit Mertajam ("Students died while playing sports", 2010). The similar incident occurred in a primary school in Merapoh when a Year Six boy died of hypertension and heart problem while attending a sports tournament in 2015 ("The trauma of the location", 2015). In 2019, a Form Four student collapsed and unconscious while participating in running event during annual sports day, and passed away minutes after arriving at the hospital ("Form Four student die", 2019). Most recently, 16-year-old students who died after doing cross-country training at school was reported (Hamsuddin, 2020).

The news of death struck by lightning while playing football (Fareez, 2019) involved a student of Maahad Tahfiz Al-Furqan in Teluk Intan and another in Shah Alam. Later in April 2016, there was news of an accident incident involving a Year One school student who died of snake bite while playing with friends in school yard (Abdul Rahim \& Subaryati, 2016) and was followed by several other incidents of snake bite in the school area., N. F., \&

The accident incidents have received a lot of unpleasant reactions especially from parents whose children are still in school because they are worried that such incidents can happen to their children. Therefore, the schools must take precautionary measures to prevent the same accident from happening again. Malaysia Ministry of Education (MOE) was aware of this and has directed the school administration to make audit reports on the state of school infrastructure and equipment (Iskandar, 2016). 
INTERNATIONAL JOURNAL OF ACADEMIC RESEARCH IN BUSINESS AND SOCIAL SCIENCES Vol. 10, No. 9, 2020, E-ISSN: 2222-6990 @ 2020 HRMARS

Ideally, schools (school leaders, teachers, and supporting staff) should constantly monitor and assess the infrastructure, equipment and sports activity management which pose risk potentials for student accidents especially when conducting Physical Education, co-curricular and sports activities. Schools need to have a specific and standardized instrument for monitoring and assessment to determine the safety level so that the risk of accidents can be prevented and controlled.

Schools also need to be aware and responsible for the safety of students especially when conducting Physical Education, co-curricular and sports activities. Every teacher involved in these activities should take safety precautions in light of the guidelines and instructions in the Professional Education Circular (SPI) of MOE regarding student safety in schools.

There are three SPI circulars related, i.e. SPI No. 1/1995: Students' personal safety during the teaching and learning of Physical Education and Health Education as well as co-curricular and sports activities within and outside the school. The contents of the circular contained information reminding Physical Education and Sports teachers to be aware of possible incidents that could cause accidents to students. Teachers should also take precautions and control steps to prevent accidents (Malaysia Ministry of Education, 1995).

SPI No. 9/2000 is a circular on student personal safety guidance in teaching Physical Education and Health Education as well as co-curricular, and sports activities within and outside the school. SPI is intended to remind the principals and headmasters to be alert to any possible harm or injury to the students. Principals and headmasters also need to take proactive steps to avoid accident incidents in schools (Malaysia Ministry of Education, 2000).

MOE SPI No. 5/2016: Safety guidelines in teaching Physical Education and Health Education and cocurricular and sports activities within and outside the school area are intended to inform safety guidelines that must be adhered to during Physical Education and Health Education and co-curricular and sports activities within and outside the school area (Malaysia Ministry of Education, 2016).

It is concluded that the content in each of these SPIs describes the safety guidelines and measures to be followed by Physical Education and Health Education teachers, co-curriculum and sports teachers, and school students. The school, especially the chairman of the Physical Education and Health Education committee or the Sports Secretary, is responsible for inspecting and maintaining sports equipment located at sports stores, sports or games areas, prohibited and dangerous areas. The schools are warned to not hold any sports activities during heavy rains and thunderstorms.

The SPI statements also contain matters related to reports of accidents or injuries where accident incidents or injuries should be investigated and reported to the principals or headmasters immediately. All accident incidents must be recorded including reporting of sports activity evaluations. Accordingly, high-skilled sports activities such as gymnastics and water activities should be taught by qualified sports teachers. The MOE make it compulsory for the school management to disseminate the contents of the SPI to the school community which involved in Physical Education, co-curricular and sports activities for safety actions. 
As a result of these reminders and actions, MOE also impulses schools to take initiatives and actions to establish Co-Curriculum Activity Safety Policy or School Safety Policy, establish Safe School Program or Occupational Safety and Health Program, and establish a School Safety Committee. The schools are also required to submit safety audit report on the state of the infrastructure such as school sports facilities and equipment (Johor Bahru District Education Office, 2016; Malaysia National Teachers' Service Union, 2013). The report has been submitted in a variety of formats, with no standard report formats. Most schools have submitted reports based on the National Audit format and there were also schools that use the Health and Safety Audit in general format by the Malaysia Ministry of Health.

Accordingly, the National Institute for Occupational Safety and Health (NIOSH) offers services to sports organizers in managing aspects of Occupational Safety and Health to ensure safety is a priority ("Sports organizers need to prioritize safety issues", 2017). The NIOSH Chairman also recommended that all schools should conduct a safety audit at least once every two years to identify any weaknesses that could be rectified for the purpose of preventing accidents (Zainul, 2016). The president of the National Parent Teacher Association (PTA), Associate Prof. Dr Mohd Ali Hassan also reminded schools to keep a record of school safety committees and weekly and annual reports that need to be submitted and corrective actions to be implemented from time to time ("Do not feel comfortable", 2016).

School is an entity under the management of the Malaysia Ministry of Education and it is appropriate that a form or format of a safety audit report be consistent. However, in Malaysia schools do not have standard or specific measuring tool or instruments for conducting safety audits that can provide inputs and indicators to identify safety levels and risk of accidents regarding facilities, equipment and management of sports activities in schools.

Therefore, the purpose of this study is to design, develop, test and produce school's sports safety audit tool to help schools in conducting safety audits on facilities, equipment and management of sports activities. The tool provides audit value that can provide inputs and indicators to identify safety and accident risks in terms of infrastructure and sports activity management in Malaysian schools. The audit report can be submitted periodically to Malaysia Ministry of Education. The report is also accessible to parents and the public in order to assess their children's safety in school.

\section{Research Objectives}

a) Determine the model of the school's sports safety audit tool.

b) Explain the method of construction of school's sports safety audit tool.

c) Assess the validity of school's sports safety audit tool.

d) Assess the reliability of school's sports safety audit tool.

e) Develop the school's sports safety audit tool.

\section{Methodology}

The method of construction of a school's sports safety audit tool (3SAT) is an adaptation of an evaluation model (Stufflebeam, 1983) that involves the aspects of context, input, process and product. The evaluation model provides an analytical and rational basis for decision-making based on 
INTERNATIONAL JOURNAL OF ACADEMIC RESEARCH IN BUSINESS AND SOCIAL SCIENCES Vol. 10, No. 9, 2020, E-ISSN: 2222-6990 @ 2020 HRMARS

the planning, structuring, implementing, researching and reviewing of decisions to track the progress of the implementation of a program (Stufflebeam, 1983). The evaluation model in this study gathers information systematically, especially in identifying the strengths and decision making of the effectiveness of 3SAT. The following is the description of the model as well as the description of the construction method of 3SAT.

\section{Context Evaluation}

Context evaluation refers to identifying the environment that is relevant to a program and explaining the actual state of the program. The evaluation involves conceptual and empirical analysis that can be obtained from formative and summative sources (Stufflebeam, 1983). The information of context evaluation helps in making decisions related to planning and allows researchers to identify unachieved needs (research objectives), and to improve what prevents them from being achieved. Context evaluation focuses on key variables to achieve the research objectives.

Based on the above description, the researchers initiated the context evaluation by conducting a retrospective conceptual analysis that identified factors of accidental incidents in sports occurring in the school environment. Among the accident incidents include being hit by a goalpost while playing football (Ibrahim, 2016), health complication problems during sports activities ("Form four student die", 2019), death by lightning struck in school field ("Tahfiz student killed by lightning", 2013; Azman, 2019), and snake bite while playing sports in the school area (Fazlina \& Betty, 2016).

The accident incidents gave the impression that the school did not have adequate monitoring and maintenance of the school's sports equipment and environment. Likewise, it seems that the Physical Education and co-curricular teachers do not care about the risk of adverse weather and are less sensitive to the student's health and fitness levels. These conceptions need to be studied and analyzed empirically.

Likewise, the Ministry of Human Resources also showed concern on the incidents and recommended that students should be taught occupational safety and health education to reduce the rates of student accident in schools (Fong, 2000).

Empirical analysis is about the safety aspects of students especially when dealing with Physical Education, co-curricular and sports programs or activities. Every teacher involved in such activities or programs should take safety measures in accordance with the guidelines and instructions in the Professional Education Circular (SPI) of Malaysia Ministry of Education regarding student safety in schools. Teachers also need to make sure that students comply with the instructions and safety guidelines when using and managing sports equipment.

In this regard, teachers need to be mindful about things or factors that are difficult to overcome or control in accident prevention. The study of Roslena's (2012) listed factors such as individual negligence, i.e. take it easy attitude and not aware of accident risk, students' playful behaviour, i.e. like to play around with equipment without supervision, equipment that is suddenly damaged, does not know how to handle equipment, does not use appropriate clothing for sports activities, and individuals in a state of fatigue or tiredness. 
There are also physical factors contributing to occurrence of accidents such as poor infrastructure, less conducive environment and weaknesses in security management systems (Bahari, 2006). Infrastructure factors include poorly maintained equipment, poor equipment structure which does not fulfil correct specifications, and lack of provision of protective gears such as face masks, safety helmets and gloves. Unsafe environmental factors include slippery floor surfaces, poor lighting, insufficient ventilation circulations, high noise levels, exposure to smoke and dust, and poorlyorganized equipment. The weaknesses in the security management system include unclear delivery and communication, less effective information on safety, and organizations that are less focused on the safety and health aspects of the school.

\section{Input Evaluation}

Input evaluation identifies the extent to which resource needs are used to select the appropriate strategies for solving problems (Fitzpatrick et al., 2011). At this stage, information on safety issues in sports is gathered to structure a design such as a measuring tool or instrument and to implement strategies towards achieving research objectives such as specifying procedures, equipment, facilities and materials (Stufflebeam, 2003).

According to the statement, the researchers obtained input to design the content of 3SAT based on several documents such as the Professional Education Circular (SPI) of Malaysia Ministry of Education regarding student safety in schools. The researchers also referred to the Handbook of Occupational Safety and Health in School issued by NIOSH (2017). Schools are encouraged to apply safety and health aspects to their students by referring to the handbook (Lee, 2008)

Furthermore, the researchers also referred to the document issued by the Department of Occupational Safety and Health (DOSH), Ministry of Human Resources (2006) that provides guidelines for the Occupational Safety and Health Act (OSHA) 1994 (Act 514). The document is referred because there are teachers and supporting staffs working in the school and they are subject to the implementation of OSHA regulations. The guidelines are to keep students safe and avoid any delinquency activities that may affect their health.

In addition, the researchers referred to the Safe Schools Integrated Program Module (Malaysia Ministry of Education, 1999), the Safe Schools Policy document (Malaysia Ministry of Education, 2002) and the 3K Program (cheerfulness, cleanliness and safety). To conclude, these three documents help the school in making action management programs and policies on school safety. The management helps the school to raise awareness and understand the need for safety as a key agenda in the education sector.

\section{Process Evaluation}

The main objective of process evaluation is to provide feedback on the extent to which activities planned can be conducted and to identify weaknesses in the process of developing a program (Stufflebeam, 1983). Such feedback can be used to modify and improve the program's design and strategy (Sufflebeam, 2003). Process evaluation also examines the quality of program 
INTERNATIONAL JOURNAL OF ACADEMIC RESEARCH IN BUSINESS AND SOCIAL SCIENCES Vol. 10, No. 9, 2020, E-ISSN: 2222-6990 @ 2020 HRMARS

implementation in which program activities are monitored, documented and evaluated by the evaluators (Fitzpatrick et al., 2011; Mertens \& Wilson, 2012).

The process evaluation for forming 3SAT for this study began with a meeting with the researchers to confirm the action plan for producing the audit tool. The first step is to organize 3SAT construction workshops specifically to determine the format and content of the audit that is relevant to the study concept. The researchers analyse and form the structure of 3SAT content based on references to relevant documents, literature reviews and analysis of research needs.

Subsequently, a pilot study of 3SAT was conducted to obtain preliminary views from teachers and school administrators on the scope of auditing and safety aspects in sports. Once 3SAT is refined, the next step is to obtain a validity evaluation from the panel of experts. The researchers have identified 11 panellists, three from the National Institute for Occupational Safety and Health (NIOSH), a senior lecturer in the field of Physical Education from a public university, and a Head of the Department of Teacher Research and Innovation, Teacher Education Institute with a doctorate of philosophy in Physical Education, three experienced secondary school teachers who teach Physical Education subject, and three experienced primary school teachers who teach Physical Education subject.

All expert panels were provided with an evaluation form with 3SAT. The panel were asked to evaluate 3SAT based on the scale of 1 (very low) to 10 (very high) over 15 items that refer to the quality of the tool. The brief details of the items evaluated are as follows: a) Overall contents are relevant to the safety audit measurement, b) Measures what to measure accurately, c) Content covers a broad range of factors related to sports safety audits, d) Sports safety audit statements are elaborated in detail, e) Demographic content is relevant to what to know, f) Safety audit content is appropriate with what to know, g) Management audit content is appropriate with what to know, h) Safety audit assessment statement (Part B) is clear , i) The rubric of safety audit evaluation section (Part B) is accurate, j) The safety management audit evaluation statement (Part $C$ ) is clear, $k$ ) The management audit evaluation rubric (Part C) is accurate, 1 ) The value of 1 (lowest) to 5 (highest) to measure the sports safety audit aspect is sufficient, $m$ ) The content of the research tools focus on sports safety audits, $n$ ) sentence structure/word order is clear, and o) sentence/word order is comprehensible.

All the contents of the instruments evaluated by the expert panel have been refined in several meetings and workshops. After obtaining good validity score from the panel of experts, the researchers conducted a pilot study at a selected school as a sample to determine the level of 3SAT reliability and suitability of the purpose of this study. The pilot study was conducted in collaboration with research assistants and teachers as enumerators in the schools involved.

\section{Product Evaluation}

The product evaluation evaluates outcomes to identify the positive and negative effects of a program being run (Mertens \& Wilson, 2012). This aspect is to compare actual results with accepted standards for evaluating, continuing, terminating, modifying or refocusing on a program (Stufflebeam, 2003).

At this stage, short and long-term outcomes are evaluated to identify whether a program objective has been achieved. The achievement of a program objective is the result of well-planned and 
INTERNATIONAL JOURNAL OF ACADEMIC RESEARCH IN BUSINESS AND SOCIAL SCIENCES Vol. 10, No. 9, 2020, E-ISSN: 2222-6990 @ 2020 HRMARS

implemented methodological techniques and processes. Product evaluation is a combination of techniques and methodologies to ensure that all decisions are recorded to assist in validating the findings of the evaluation (Mertens \& Wilson, 2012; Stufflebeam, 2003).

Product evaluation in this study resulted in five types of 3SAT involving auditing of school infrastructure: a) Sports Store / Sports Management Room, b) Field, c) Open Court, d) Covered Hall, and e) Indoor Hall. The infrastructure is audited because the activities and management of Physical Education, co-curriculars and sports are often conducted at these locations. The audit report is intended to provide inputs on indices and indicators to identify the safety level and risk of accidents on infrastructure and management of sports activities in schools.

The design of the audit tool contains Part A, i.e. the demographic information of the school infrastructure. This section requires information on size or measurement, location, and usage activities in sports stores/sports management rooms, fields, courts, and halls. Part B is the scope of safety audits in sports focusing on the elements of environment, control and information. Part $\mathrm{C}$ also covers the scope of safety management audits related to maintenance and records. Table 2 is the scope of the audit and number of items for each 3SAT.

Table 2

Scope of Audit and Number of Items for Each Sport Safety Audit Tool

\begin{tabular}{|c|c|c|c|c|c|c|}
\hline \multirow[b]{2}{*}{ Part } & \multirow[b]{2}{*}{ Audit Scope } & \multicolumn{5}{|c|}{ Item Number } \\
\hline & & $\begin{array}{l}\text { Sport } \\
\text { Store }\end{array}$ & Field & Court & Open Hall & $\begin{array}{c}\text { Closed } \\
\text { Hall }\end{array}$ \\
\hline \multirow{3}{*}{ Sports safety } & Environment & 16 & 10 & 10 & 7 & 8 \\
\hline & Control & 18 & 3 & 3 & 2 & 3 \\
\hline & Information & 5 & 5 & 5 & 4 & 4 \\
\hline \multirow{3}{*}{$\begin{array}{l}\text { Safety } \\
\text { management } \\
\text { in sports }\end{array}$} & Management & 3 & 5 & 3 & 3 & 2 \\
\hline & Record & 13 & 4 & 4 & 4 & 4 \\
\hline & Total & 55 & 27 & 25 & 20 & 21 \\
\hline
\end{tabular}

Each scope of audits and items has a rubric evaluation scale from 1 to 5 that involves observation methods. Evaluation scores obtained from each audited item were analysed descriptively and transformed to percentage values. Percentage value information is an indicator for determining the level of sports safety based on the Sports Safety Index in the schools being studied.

Table 3 is the Sports Safety Index in the schools which contains the evaluation percentages and is coordinated by color and safety indicators to determine the level of sports safety at the audited location. The index is a summary of audit reports as indicators for identifying the level of safety and risk of accidents regarding infrastructure and management of sports activities in schools. 
INTERNATIONAL JOURNAL OF ACADEMIC RESEARCH IN BUSINESS AND SOCIAL SCIENCES Vol. 10, No. 9, 2020, E-ISSN: 2222-6990 @ 2020 HRMARS

Table 3

Sports Safety Index in Schools

\begin{tabular}{clll}
\hline Evaluation Percentage & Color & \multicolumn{1}{c}{ Safety Indicator } & Safety Level \\
\hline $80.1-100$ & Blue & Lowest potential accidents & Very High \\
$60.1-80$ & Green & Low potential accidents & High \\
$40.1-60$ & Yellow & Moderate potential accidents & Moderate \\
$20.1-40$ & Orange & High potential accidents & Low \\
$1-20$ & Red & Highest potential accidents & Very Low \\
\hline
\end{tabular}

Figure 1 is the example of safety audit evaluation calculation form at sports store/sports management room and sports safety index report of a school. The calculation method begins with summing up the evaluation score for each audit scope. The total score is divided by the number of items based on the audit scope to obtain the actual evaluation score. The evaluation scores are converted into percentage values to determine the color, indicator and level of sports safety in sports store/sports management room based on the Safety Index.

\begin{tabular}{|c|c|c|c|c|c|c|}
\hline & Criteria & $\begin{array}{c}\text { Evaluation } \\
\text { Scores }\end{array}$ & Evaluation Percentage & Color & $\begin{array}{c}\text { Safety } \\
\text { Indicator }\end{array}$ & Safety Level \\
\hline B. & \multicolumn{5}{|l|}{ SAFETY AUDIT } & \\
\hline i. & Environment & & $\begin{array}{l}\div 80 \text { (16 items }) \times 100 \\
=\end{array}$ & & & \\
\hline ii. & Control & & $\begin{array}{l}\div 90 \text { (18 items) } \times 100 \\
=\end{array}$ & & & \\
\hline iii. & Information & & $\div 25(5$ items $) \times 100=$ & & & \\
\hline \multicolumn{2}{|c|}{ Overall Total } & & $\div 195 \times 100=$ & & & \\
\hline C & \multicolumn{5}{|c|}{ MANAGEMENT AUDIT } & \\
\hline i. & Management & & $\div 15$ (3 items) & & & \\
\hline ii. & $\begin{array}{l}\text { Record } \\
\text { management }\end{array}$ & & $\div 65$ (13 items) & & & \\
\hline \multicolumn{2}{|c|}{ Overall Total } & & $\div 80 \times 100=$ & & & \\
\hline \multicolumn{2}{|c|}{ OVERALL SCORE } & & $\div 275 \times 100=$ & & & \\
\hline
\end{tabular}

Figure 1. Audit evaluation form in sports store/sports management room and report on sports safety index in school.

\section{Results}

This section presents the results of 3SAT analysis in terms of validity and reliability. The validity of 3SAT data from the 11 panel evaluators was analyzed descriptively and reported in terms of mean and standard deviation. The results of the data analysis showed that all the panel evaluators rated a mean of 9 out of 10 on the 15 items evaluated for the five types of 3SAT. The overall validity value for 3SAT was 9.17 and the standard deviation was .497. The mean value was transformed into percentage and was found to be $91.70 \%$. The validity value was at an excellent level and was relevant to the content of the study (Garson, 2016). The result of the validity value implied that 3SAT is valid and can be administered for this study. Table 4 is a descriptive statistic of the validity of 3SAT from the panel of experts on the 15 items evaluated. 
INTERNATIONAL JOURNAL OF ACADEMIC RESEARCH IN BUSINESS AND SOCIAL SCIENCES

Vol. 10, No. 9, 2020, E-ISSN: 2222-6990 @ 2020 HRMARS

Table 4

3SAT Validity Evaluation by the Panellists Based on the 15 Items, $N=11$

\begin{tabular}{|c|c|c|c|c|c|c|c|c|c|c|}
\hline \multirow[t]{2}{*}{ Items } & \multicolumn{2}{|c|}{ Sport Store } & \multicolumn{2}{|c|}{ Field } & \multicolumn{2}{|c|}{ Court } & \multicolumn{2}{|c|}{$\begin{array}{l}\text { Open } \\
\text { Hall }\end{array}$} & \multicolumn{2}{|c|}{$\begin{array}{c}\text { Closed } \\
\text { Hall }\end{array}$} \\
\hline & $M$ & $S D$ & $M$ & $S D$ & $M$ & $S D$ & $M$ & $S D$ & $M$ & $S D$ \\
\hline All content is relevant & 9.00 & .447 & 9.09 & .539 & 9.36 & .505 & 9.20 & .632 & 9.50 & .527 \\
\hline Measure accurately & 9.18 & .603 & 8.91 & .701 & 9.27 & .467 & 9.10 & .568 & 9.30 & .483 \\
\hline Covers a broad range of factors & 9.18 & .405 & 9.09 & .539 & 9.18 & .405 & 9.10 & .568 & 9.30 & .483 \\
\hline $\begin{array}{l}\text { Statement is elaborated in } \\
\text { detail }\end{array}$ & 9.09 & .539 & 8.91 & .701 & 9.09 & .302 & 9.10 & .316 & 9.50 & .527 \\
\hline $\begin{array}{l}\text { Demographic content is } \\
\text { relevant }\end{array}$ & 9.36 & .505 & 9.18 & .751 & 9.36 & .809 & 9.20 & .919 & 9.20 & .632 \\
\hline Safety audit content is accurate & 9.09 & .831 & 8.82 & .751 & 9.09 & .701 & 9.20 & .632 & 9.30 & .823 \\
\hline $\begin{array}{l}\text { Management audit content is } \\
\text { accurate }\end{array}$ & 9.27 & 647 & 9.00 & .775 & 9.27 & .647 & 9.30 & .675 & 9.30 & .823 \\
\hline Safety audit evaluation is clear & 9.27 & .647 & 9.18 & .751 & 9.18 & .603 & 9.20 & .632 & 9.20 & .632 \\
\hline Safety audit rubric is accurate & 9.18 & .751 & 9.00 & .632 & 9.09 & .539 & 9.10 & .568 & 9.30 & .675 \\
\hline $\begin{array}{l}\text { Management audit evaluation } \\
\text { is clear }\end{array}$ & 9.09 & .831 & 9.09 & 831 & 9.00 & .775 & 9.20 & .632 & 9.10 & .568 \\
\hline $\begin{array}{l}\text { Management audit rubric is } \\
\text { accurate }\end{array}$ & 9.27 & .786 & 9.00 & .632 & 9.00 & .775 & 9.20 & .422 & 9.20 & .632 \\
\hline $\begin{array}{l}\text { Appropriation of evaluation } \\
\text { mark }\end{array}$ & 9.00 & .894 & 9.27 & .786 & 9.18 & .603 & 9.30 & .675 & 9.30 & .675 \\
\hline Content is focused & 9.00 & .894 & 9.00 & 1.000 & 9.36 & .505 & 9.20 & .632 & 9.40 & .516 \\
\hline Sentence structure is clear & 9.00 & .894 & 9.27 & .786 & 9.27 & .647 & 9.10 & .876 & 9.30 & .823 \\
\hline $\begin{array}{l}\text { Sentence structure is } \\
\text { comprehensible }\end{array}$ & 9.00 & .894 & 9.27 & 786 & 9.36 & .505 & 9.10 & 8 & 9.30 & .823 \\
\hline Overall mean & 9.13 & .522 & 9.07 & .621 & 9.20 & .408 & 9.17 & .461 & 9.30 & .479 \\
\hline
\end{tabular}

Subsequently, a pilot study was conducted to determine the reliability of 3SAT. A total of 10 secondary and primary, urban and rural schools were randomly selected to test the reliability of the five types of 3SAT. The researchers, research assistants and teachers as enumerators in the participating schools used observation methods to conduct audits based on items that are listed in the scope of audit. Each audit scope has an evaluation scale of 1 to 5 .

Out of the 10 schools surveyed, audits were conducted on 10 sports stores/sports management rooms, and 9 audits were conducted on the field and open court as one school did not have all the listed infrastructure. It also found that only three open hall and indoor halls could be audited as seven other schools did not have the infrastructure to carry out Physical Education, co-curricular and sports activities. Table 5 is the statistics of 3SAT reliability value. 
INTERNATIONAL JOURNAL OF ACADEMIC RESEARCH IN BUSINESS AND SOCIAL SCIENCES Vol. 10, No. 9, 2020, E-ISSN: 2222-6990 @ 2020 HRMARS

Table 5

Reliability Evaluation on the 5 Types of Sports Safety Audit Tools (3SAT)

\begin{tabular}{lcccc}
\hline Sports Safety Audit Tool & $\mathrm{N}$ & $\alpha$ & $\begin{array}{c}\alpha \text { Based on Item } \\
\text { Standard }\end{array}$ & $\begin{array}{c}\text { Number } \\
\text { of Items }\end{array}$ \\
\hline Sports Store / Sports Management & 10 & .863 & .890 & 55 \\
Room & 9 & .842 & .871 & 27 \\
Field & 9 & .816 & .864 & 25 \\
Open court & 3 & .738 & .770 & 20 \\
Covered Open Hall & 3 & .647 & .669 & 21 \\
Indoor Hall &
\end{tabular}

Referring to the concept of validity and reliability as coined by Garson (2016), the auditing reliability of 3SAT in Sports Store/Sports Management Room, Field and Open Court is good and consistent while the auditing reliability of 3SAT in Covered Open Hall is adequate and consistent, the auditing reliability of 3SAT of Indoor Hall is acceptable for the purpose of this study. Thus, 3SAT has excellent validity and relevance to the content of the study while 3SAT reliability is good, sufficient, consistent and acceptable for studies as evinced in Tables 4 and 5.

\section{Summary and Conclusion}

The development of school's sports safety audit tool (3SAT) is based on an evaluation model (Stufflebeam, 1983). The model is used to provide analytical and systematic research tools for obtaining empirical evaluation in decision making. The 3SAT design involves evaluation elements in terms of context, input, process and product. The context evaluation involves a retrospective conceptual and empirical analysis of identifying factors of accident incidents in sports that occur in the school environment. The input evaluation is to identify the extent of the need of resources based on several documents on sports safety to select the appropriate strategy for solving the research problem. The process evaluation is to provide feedback on the extent to which the planned activities are carried out and to identify the validity and reliability of the 3SAT formation process. The product evaluation is to identify the impact of the results of the study through 3SAT based on the Sports Safety Index in the schools studied.

The 3SAT method of construction based on the evaluation model (Stufflebeam, 1983) is proven as a steadfast audit tool with excellent validity and relevance to the content of the study while the reliability is good, adequate, consistent and acceptable for this study.

\section{Acknowledment}

This research is funded by the Fundamental Research Grant Scheme. The research code is 2019-0040107-02 (FRGS / 1/2018 / SSI09 / UPSI / 01/4) entitled CAI (Context, Audit, Index) Approach to Risk Management in Sports Safety in Schools. The researchers are indebtedness to the Research Management and Innovation Centre of Sultan Idris Education University for the grant. 
INTERNATIONAL JOURNAL OF ACADEMIC RESEARCH IN BUSINESS AND SOCIAL SCIENCES Vol. 10, No. 9, 2020, E-ISSN: 2222-6990 @ 2020 HRMARS

\section{References}

Abdul Rahim, N. F., \& Subaryati, B. (2016). Murid Tahun 1 maut dipatuk ular di sekolah. Berita Harian.Retrieved from https://www.bharian.com.my/taxonomy/ term/11/2016/04/145320/murid-tahun-satu-maut-dipercayai-dipatuk-ular

Azman, F. (2019). Seorang maut, seorang koma, dua lagi cedera dipanah petir ketika bermain bola. Astro Awani. Retrieved from http://www.astroawani.com/berita-malaysia/seorang-mautseorang-koma-dua-lagi-cedera-dipanah-petir-ketika-bermain-bola-200751

Bahari, I. (2006). Pengurusan Keselamatan dan Kesihatan Pekerjaan. 2nd Edition Kuala Lumpur McGraw-Hill, Malaysia, ISBN-10: 9833219357, pp: 395.

Department of Occupational Safety and Health. Ministry of Human Resources. (2006). Garis panduan bagi akta keselamatan dan kesihatan pekerjaan 1994 (Akta 514). Retrieved from http://dosh.mohr.gov.my/

Do not feel comfortable with school safety reports (2016), Malaysian Digest. Retrieved from http://malaysiandigest.com/bahasa-malaysia/611972-jangan-rasa-selesadengan-laporankeselamatan-sekolah.html

Fitzpatrick, J., Sanders, J., \& Worthen, B. (2011). Program evaluation: Alternative approaches and practical guidelines (4th Ed.). New York: Allyn \& Bacon. Canadian Publisher: Pearson. ISBN: 978-0-205-57935-8.

Fong, C. O. (2000). Speech Text: Pelancaran kempen bulan keselamatan dan kesihatan pekerjaan. Kuala Lumpur: Kementerian Sumber Manusia.

Form four student die during annual sports (2019, February 17), Borneo Today. Retrieved from https://www.borneotoday.net/pelajar-tingkatan-empat-meninggal-dunia-semasa-sukantahunan/

Garson, D. (2016). Validity \& Reliability, 2016 Edition. Asheboro, NC: Statistical Associates Publishers Hamsuddin, A. A. (2020). Meninggal selepas latihan rentas desa. Berita Harian. Retrieved from https://www.bharian.com.my/berita/kes/2020/01/646658/meninggal-selepas-latihanrentas-desa.

Ibrahim, R. (2016). Pelajar maut dihempaptiang gol. Harian Metro. Retrieved from https://www.hmetro.com.my/node/151194

Iskandar, P. W. (2016). Sekolah diarah serah laporan audit infrastruktur. Berita Harian. Retrieved from https://www.bharian.com.my/berita/nasional/2016/07/

174678/Sekolah-diarah-serah-laporan-audit-infrastruktur

Johor Bahru District Education Office. (2016). JPA'1002.39/700-5/6/1 Jilid3 (75) 14 Julai 2016. Retrieved from https://www.scribd.com/document/391250508/semakan-peralatan-sukan

Lee, L. T. (2008). Keselamatan di sekolah: Pembentukan budaya kerja selamat dan sihat. (31 December 2008). Retrieved from http://lamthyelee.blogspot.com/2008/12/keselamatan -di-sekolah-pembentukan.html

Malaysia Ministry of Education. (2016). KP/KPPM/6 Jld. 2 (22), 24 Ogos 2016. Retrieved from https://www.moe.gov.my/pekeliling/2274-surat-pekeliling-ikhtisas-bilangan-5tahun-2016-panduan-keselamatan-semasa-pengajaran-pendidikan-jasmani-dn-kesihatanserta-kegiatan-kokurikulum-dan-sukan-di-dalam-dan-di-luar-kawasan-sekolah/file

Malaysia Ministry of Education. (2000). KP (BS) 8591/Jld.XVI (9), 30 Mac 2000. Retrieved from https://www.moe.gov.my/pekeliling/2004-surat-pekeliling-ikhtisas-bilangan 
INTERNATIONAL JOURNAL OF ACADEMIC RESEARCH IN BUSINESS AND SOCIAL SCIENCES Vol. 10, No. 9, 2020, E-ISSN: 2222-6990 @ 2020 HRMARS

-9-tahun-2000-panduan-keselamatan-diri-pelajar-semasa-pengajaran-pendidikan-jasmanidan-kesihatan-serta-kegiatan-kokurikulum-dan-sukan-di-dalam-dan-di-luar-kawasansekolah/file

Malaysia Ministry of Education. (1999). Program Bersepadu Sekolah Sihat. Kuala Lumpur: KPM, Bahagian Sekolah.

Malaysia Ministry of Education. (1995). KPM KP (BS) 8591/Jld.VIII / (83), 6 April 1995.

Retrieved from https://www.moe.gov.my/pekeliling/2071-surat-pekeliling-ikhtisas-bilangan1-tahun-1995-keselamatan-diri-pelajar-semasa-pengajaran-pendidikan-jasmani-dan-

kesihatan-serta-kegiatan-kokurikulum-dan-sukan-di-dalam-dan-di-luar-kawasansekolah/fileMalaysia Ministry of Education. (2002). Konsep dan manual sekolah selamat: Panduan perlaksanaan menjadi sekolah, komuniti dan keluarga selamat untuk kanak-kanak. Kuala Lumpur: KPM.

Malaysia National Teachers' Service Union. (2013). Kajian audit keselamatan sekolah. Jabatan Perancangan Bandar dan Desa, Semenanjung Malaysia di bawah program NKRA.

Mertens, D., \& Wilson, A. T. (2012). Program evaluation theory and practice: A comprehensive guide. New York: Guilford Press. Retrieved from https://www.researchgate.net/publication/235930775_Program_evaluation_theory_and_pr actice_A_comprehensive_guide

National Institute of Occupational Safety and Health (NIOSH). (2017). Buku panduan keselamatan dan kesihatan pekerjaan untuk sekolah tahfiz. Bandar Baru Bangi, Selangor: Kementerian Sumber Manusia Malaysia.

Roslena, C. J. N. (2012). Tahap kesediaan pelajar kejuruteraan politeknik terhadap keselamatan di dalam bengkel. [Unpublished master's thesis]. Universiti Tun Hussein Onn Malaysia, Johor.

Sports organizers need to prioritize safety issues (2017), Berita Harian. Retrieved from https://www.bharian.com.my/berita/nasional/2017/12/364191/ penganjur-sukan-perlu-utama-isu-keselamatan

Students died while playing sports (2010), The Borneo Post. Retrieved from http://www.theborneopost.com/2010/04/01/pelajar-meninggal-dunia-ketika-sedangbersukan/.

Stufflebeam, D. L. (2003). The CIPP model of evaluation. In T. Kellaghan, D. Stufflebeam \& L. Wingate (Eds.), Springer international handbooks of education: International handbook of educational evaluation. Retrieved from http://www.credoreference com.ezproxy. lib.ucalgary. ca/entry/spredev/the_cipp_model_for_evaluation.

Stufflebeam, D. L. (1983). The CIPP model for program evaluation. In G. F. Madaus, M. Scriven, \& D. L. Stufflebeam (Eds.), Evaluation models (Chapter 7, pp. 117-141). Boston: Kluwer-Nijhoff.

Tahfiz student killed by lightning (2013), Kosmo. Retrieved from http://www.Kosmo.com.my/kosmo/content.asp?y=0217\&pub=kosmo\&sec=Terkini\&pg=bt_ 01.htm

The trauma of the location of the child 'goes' (2015), Sinar Harian. Retrieved from http://www.sinarharian.com.my/semasa/trauma-lokasi-sama-anak-pergi-1.365986. http://pahangku.blogspot.com/2015/03/kuala-lipis-trauma-lokasi-sama-anak.html 
INTERNATIONAL JOURNAL OF ACADEMIC RESEARCH IN BUSINESS AND SOCIAL SCIENCES

Vol. 10, No. 9, 2020, E-ISSN: 2222-6990 @ 2020 HRMARS

Zainul, M. N. (2016). Audit keselamatan di sekolah, universiti 2 tahun sekali-NIOSH. Retrieved from https://www.bharian.com.my/berita/nasional/2016/02/125007

/audit-keselamatan-di-sekolah-universiti-2-tahun-sekali-niosh 